\title{
Seasonal effects on mortality rates and resprouting of stems treated with glyphosate in the invasive tree of heaven (Ailanthus altissima (Mill.) Swingle)
}

\section{Emilio Badalamenti, Ettore Barone \& Tommaso La Mantia}

To cite this article: Emilio Badalamenti, Ettore Barone \& Tommaso La Mantia (2015) Seasonal effects on mortality rates and resprouting of stems treated with glyphosate in the invasive tree of heaven (Ailanthus altissima (Mill.) Swingle), Arboricultural Journal, 37:3, 180-195

To link to this article: http://dx.doi.org/10.1080/03071375.2015.1112163

曲 Published online: 02 Mar 2016.

Submit your article to this journal ¿

Q View related articles $\square$

View Crossmark data ¿

Citing articles: 1 View citing articles 5 


\title{
Seasonal effects on mortality rates and resprouting of stems treated with glyphosate in the invasive tree of heaven (Ailanthus altissima (Mill.) Swingle)
}

\author{
Emilio Badalamenti (D), Ettore Barone and Tommaso La Mantia* \\ Department of Agricultural and Forest Sciences, University of Palermo, 90128 Palermo, Italy
}

\begin{abstract}
Tree of heaven (Ailanthus altissima) is regarded as invasive within urban and natural areas worldwide. Efficient methods to control it are significantly needed if we are to limit its well-known environmental and economic impacts. Up to now the use of herbicides has proven necessary since following mechanical damage, Ailanthus vigorously resprouts. However, the seasonal response of Ailanthus stems, treated with herbicides, has never been assessed. We compared the control efficacy recorded in autumn, winter and summer in an abandoned suburban citrus grove in Sicily, under Mediterranean-climate conditions. Glyphosate was injected within drill holes made in knee-high cut trees. Tree mortality and the resprouting ability of treated stems were significantly affected by the application timing and by diameter class of stems. Mortality was significantly lower in winter treatments within the smaller diameter class. Within the larger diameter class, only autumn treatments showed a notably higher mortality rate and a significantly lower growth of sprouts. Hence, autumn interventions are strongly recommended to effectively treat Ailanthus. Mortality was notably higher in the smaller diameter class. Our results confirm the importance of early intervention to control Ailanthus, also showing that the choice of the season is crucial to obtaining satisfactory control of its resprouting ability.
\end{abstract}

Keywords: alien tree; control techniques; herbicides; stem injection; Mediterranean basin

\section{Introduction}

Invasive alien species are widely acknowledged as a major threat to socio-economic activities, biodiversity preservation, as well as human health (Mack et al., 2000). In addition urban and forest environments are increasingly facing invasion by non-native trees (Casella \& Vurro, 2013; Celesti-Grapow \& Blasi, 1998; Green, 2003; Maringer, Wohlgemuth, Neff, Pezzatti, \& Conedera, 2012). Spread of Ailanthus altissima (Mill.) Swingle is particularly favoured by anthropic disturbances or cutting (Motta, Nola, \& Berretti, 2009; Radtke et al., 2013; Sitzia, Trentanovi, Marini, Cattaneo, \& Semenzato, 2013). Urgent interventions are therefore needed in order to tackle this global environmental issue, especially focusing on the most harmful species, in order to contain their rising spread and damaging effects. Along the introduction-naturalisation-invasion continuum, the control efficacy becomes much higher, and the costs much lower, if we act promptly (Hobbs \& Humphries, 1995; Myers, Simberloff, Kuris, \& Carey, 2000). Thus, the timeliness of intervention is of paramount importance if we are to get successful control. Beyond certain levels of spread, total elimination is virtually impossible and

\footnotetext{
*Corresponding author. Email: tommaso.lamantia@unipa.it
} 
impracticable, unless at great cost and supported for a long period of time. This is the case with many invasive plants, for which a useful approach is to identify areas with different priority interventions so as to better allocate economic and human resources where it is deemed more necessary and where an effective control can be achieved (van Wilgen et al., 2012). Eradication, that is the complete removal of any living population and propagule of a given species from a defined area, may be performed through physical, chemical or biological means. Biological control appears to be the most effective, also costwise, method to eradicate invasive plants; for instance, control based on living organisms has proven to significantly reduce the invasive potential of many Australian Acacias (Impson, Moran, \& Hoffmann, 2004). However, the long experimentation time and the difficulty in identifying suitable biocontrol agents make such choices not applicable to all the target species, at least taking a short-time perspective (Langeland, Ferrell, Sellers, MacDonald, \& Stocker, 2011). Thus, physical treatments, such as cut-stump or girdling, become necessary for many invasive plants, and these physical treatments are generally performed together with the application of herbicides. Such intervention requires more attention, careful management and economic investments than simple mechanical control, because the use of herbicides implies that: application rates, intervention techniques and the types of chemicals have to be decided, also taking into account all the possible environmental risks. The use of chemicals, despite being generally avoided or severely regulated in natural areas, is now considered an inevitable and important tool to tackle invasive plants; such control strategies are frequently included in the management plans of many protected areas and natural parks (Constán-Nava, Bonet, Terrones, \& Albors, 2007; Tu, Hurd, Randall, \& The Nature Conservancy, 2001).

One of the most prominent tree invaders worldwide is A. altissima (also known as Tree-of-Heaven, hereafter Ailanthus), a fast-growing deciduous tree that is particularly aggressive and widespread in temperate and Mediterranean-climate areas (Badalamenti, Barone, Pasta, Sala, \& La Mantia, 2012; Meloche \& Murphy, 2006; Vilà et al., 2006). The broad use, mainly for ornamental or afforestation purposes, and peculiar eco-physiological and reproductive traits allowed the naturalisation and spread of Ailanthus from its native range - China and north Vietnam - to Europe, USA and many other regions around the world (Kowarik \& Säumel, 2007). Ailanthus reproduces effectively either by seed or via root sprouts. It can survive under a wide range of ecological conditions and its winged seeds are perfectly adapted to long-dispersal distances. It has a particularly high growth rate during the early stages of life. Moreover, Ailanthus is well adapted to cope with human or natural disturbances, because it may vigorously resprout either from injured stems, root collars or lateral roots (Aldrich et al., 2010; Bowker \& Stringer, 2011; Maringer et al., 2012; Meggaro \& Vilà, 2002). Even root fragments 1-cm long and a few mm wide are able to produce new suckers (Inverso \& Bellani, 1991). In addition, main highways and railways, where Ailanthus commonly occurs, may act as a substantial source of seed to neighbouring natural and semi-natural areas, thus increasing its rate of spread (Aldrich et al., 2010; McAvoy, Snyder, Johnson, Salom, \& Kok, 2012). Furthermore, in invaded environments, Ailanthus releases allelopathic compounds that may affect competitive dynamics with the native co-occurring species, especially during the seedling stage (Gómez-Aparicio \& Canham, 2008), when competition for resources is generally higher. Despite being a typical species affecting urban and frequently disturbed sites (Celesti-Grapow \& Blasi, 2004), in recent years Ailanthus has been increasingly able to establish within woodlands, shrublands, grasslands and riparian areas, where it represents 
a growing threat for native habitat conservation as well as ecosystem functioning (Fotiadis, Kyriazopoulos, \& Fraggakis, 2011; Traveset et al., 2008).

Ailanthus' invasive process is initially favoured directly by man, through the introduction in a given urban area, generally for ornamental purposes and to stabilise steep slopes, and indirectly as a consequence of increased disturbance. Then, it is capable of spreading into relatively undisturbed adjacent forested sites where at first it readily establishes along edges and in clearings (Knapp \& Canham, 2000; Sitzia et al., 2013), as a typical heliophilous pioneer plant. A crucial role in the establishment into inner parts of woodlands is played by the remarkable ability of root suckers to propagate vegetatively and resprouts have a higher capacity than seedlings to withstand sub-optimal ecological conditions, such as shade under canopy, or disturbance factors like wildfires (Kowarik, 1995; Lewis, 2007; Maringer et al., 2012; Meggaro \& Vilà, 2002). As soon as the dominant native species cover is reduced, Ailanthus is able to quickly take advantage of the increased light availability and can rapidly reach the top of the canopy due to its outstanding growth rates (Kowarik, 1995; Meggaro \& Vilà, 2002). Gradually, Ailanthus is thus able to stand out and eventually dominate the underlying native species.

In order to contain the ecological and socio-economic consequences triggered by Ailanthus invasion, many control trials have been recently conducted all around the world with the aim of identifying the most suitable control techniques to eradicate it effectively (Bowker \& Stringer, 2011; Burch \& Zedaker, 2003; Constán-Nava, Bonet, Pastor, \& Lledó, 2010; DiTomaso \& Kyser, 2007; Lewis \& McCarthy, 2006; Meloche \& Murphy, 2006). The main common result of previous studies is that only physical treatment combined with herbicide application is really effective in significantly curtailing Ailanthus resprouting ability, thus allowing recovery for the affected natural vegetation and the ecological restoration of native habitats.

In most of the Mediterranean countries and islands (Vilá et al., 2006), Ailanthus is a serious plant invader, with an outstanding competitive ability against local species. As a confirmation of this, Ailanthus is the only woody species regarded as invasive in all the Italian regions, also in semi-natural and natural habitats (Celesti-Grapow, Pretto, Carli, \& Blasi, 2010). Such a pattern is found in Sicily, where the distribution of Ailanthus stands is so wide (Badalamenti et al., 2012) that by now they represent a specific forest type in the recent Sicilian forest inventory (Camerano, Cullotta, \& Varese, 2011). They are generally associated with a reduction in local biodiversity as well as a deep alteration of ecosystem and landscape characteristics (Badalamenti et al., 2012; Traveset et al., 2008). Secondary succession is totally hampered by Ailanthus, which is able to establish almost monospecific and rather close stands. Also Mediterranean woodlands and grasslands, even if not subjected to anthropogenic disturbances or exploitation, may be exposed to Ailanthus invasion and to its consequently negative ecological effects. The widespread presence within protected areas such as natural parks or Sites of Community Importance makes Ailanthus control a high priority in the conservation strategies of native Mediterranean ecosystems (Badalamenti et al., 2012; Constán-Nava et al., 2010; Giunti, Masiaj, Quilghini, \& Sposimo, 2011). For this reason, as many as 13 LIFE projects (financial instruments adopted by the European Union with the aim of protecting the environment in its broader sense or biodiversity and natural ecosystem characters) have been specifically or partially focused on Ailanthus control within areas of conservation value (see http://ec.europa.eu/environment/life/project). The navigation of the websites related to the above-mentioned projects paints a quite alarming picture of the wide range of European habitats seriously threatened by this invasive tree. 
We conducted a field experiment to investigate the effect of season on the resprouting ability of Ailanthus stems treated with glyphosate. This influence has never been quantified in previous projects and could give some useful information for effective management of Ailanthus in invaded areas. Glyphosate is a common systemic herbicide that has been successfully tested against Ailanthus through different techniques such as cutstump, stump or stem injection, and hack-and-squirt (Badalamenti \& La Mantia, 2013; Bowker \& Stringer, 2011; Constán-Nava et al., 2010; DiTomaso \& Kyser, 2007; Lewis \& McCarthy, 2006; Meloche \& Murphy, 2006). Only stump injection seems to be particularly ineffective (DiTomaso \& Kyser, 2007). In our study, the herbicide was applied through a stem injection technique in three seasons: autumn, winter and summer, corresponding to different Ailanthus phenological phases: just prior to winter dormancy (November), during winter dormancy (February) and during full vegetative growth (July). Spring treatments, at the beginning of the vegetative growth, were not included because phloem transport is initially directed towards aboveground organs and not roots (DiTomaso \& Kyser, 2007; Hoshovsky, 1988), which must be reached to definitely kill the trees and impede resprouting. Our main goal was to identify the most suitable season to effectively eradicate Ailanthus through a stem injection technique. The percentage of dead trees, as well as the number and the height of the sprouts were evaluated to test the efficacy of the treatments. As far as we know, this is one of the few scientific research studies on the techniques to control A. altissima conducted in Italy.

\section{Materials and methods}

\section{Study site}

The trials were carried out on the campus of the University of Palermo $\left(38^{\circ} 06^{\prime} 24.46^{\prime \prime} \mathrm{N}\right.$, $13^{\circ} 21^{\prime} 02.58^{\prime \prime} \mathrm{E} ; 45 \mathrm{~m}$ a.s.l.), a suburban area of about 1 ha. The study site is characterised by a typical Mediterranean climate, with yearly rainfalls around $600 \mathrm{~mm}$, concentrated during the coldest months, and a yearly average temperature of $19^{\circ} \mathrm{C}$ (Drago, Lo Bianco, \& Monterosso, 2002). The soil is "Terra Rossa", developed on Cretaceous limestone formations and on Pleistocenic calcarenite platforms. Some 50 years ago, Ailanthus was originally planted for ornamental purposes near an orchard, but it soon escaped and became naturalised. Then, because of the total absence of control, it has been able to establish and consistently spread through the last twenty years. Although some orchard trees, mainly Citrus spp., are still present in the area, Ailanthus is now the dominant species and further increases in cover are very likely to take place in the next years.

\section{Literature review}

Prior to defining our experimental design, we searched for published papers dealing with Ailanthus control. An extensive literature was found but despite claims these were not always adequately supported by sufficient experimental data. Thus, we selected only the studies containing a detailed description of the experimental design, the adopted control techniques and a clear quantification of the results.

\section{Experimental design}

The herbicide treatment's efficacy was evaluated and compared across three phenological phases: (a) just before winter dormancy: November 2011 (NOV); (b) during winter dormancy: February 2012 (FEB); (c) and in the middle of growing season: July 2012 
(JUL). In our study site, Ailanthus winter dormancy starts at the end of November and lasts until the end of March. Our research was conducted in an experimental area of about 1 ha, characterised by uniform ecological conditions (slope, herbaceous cover, stoniness, etc.), and where Ailanthus individuals, both young and mature, were randomly scattered over the whole area. More than 180 stems were selected and labelled according to a completely randomised design. They were chosen according to diameter class: 90 stems with diameter at knee height $(\mathrm{DKH}) \leq 8 \mathrm{~cm}$ (A) and 90 with $8<\mathrm{DKH} \leq 15 \mathrm{~cm}$ (B). Also, nine plants with $\mathrm{DKH}>15 \mathrm{~cm}$, three per season, were treated but these results have not been statistically analysed due to their small number.

Two treatments were applied: cutting and herbicide application (treated) or cutting without herbicide application (control). Within each diameter class, three replicates per season and treatment, and five stems per replicate, were considered. Only single Ailanthus plants originating from seed, never coppiced, were taken into account.

The final effect of treatments was evaluated on December 2013, corresponding to 24, 21 and 16 months after NOV, FEB and JUL treatments, respectively. For each stem we evaluated its mortality rate (\%) and the number and height of sprouts deriving from the survived stems. The parameters were compared by a one-way ANOVA followed by a Tukey's HSD test $(p \leq 0.05)$ using SYSTAT $^{\circledR}$ ver.12.02.00 software. Mortality data were arcsine-transformed before analysis in order to achieve normality.

\section{Herbicide and application technique}

Glyphosate (Myrtos ${ }^{\circledR} 360$ SL, NUFARM Italia srl, Milan - $360 \mathrm{~g}$ ae/L), a systemic nonselective herbicide, was applied by means of a plastic syringe directly on the cut surface of knee-high trees (CKHT). Such a method of application was considered more practical and easy to perform than stump injection (DiTomaso \& Kyser, 2007). Stems in the $A$ diameter class received $1 \mathrm{ml}$ of glyphosate, whereas $2 \mathrm{ml}$ was applied to stems belonging to the $B$ diameter class. Stems with a DKH $>15 \mathrm{~cm}$ received $3 \mathrm{ml}$ of herbicide.

Each cut stem was covered with black plastic bags soon after the injection was made, so as to avoid any possible contact between the herbicide and the environment (birds for example).

\section{Results}

Treatments were significantly affected by application timing and diameter class. In all seasons, mortality was significantly higher in the treated ones than in the control stems (Table 1). Within the $A$ diameter class, tree mortality was significantly lower in FEB than in NOV and JUL treatments (Table 1). Within the upper diameter class, mortality in NOV was significantly higher than in FEB but no other significant difference was detected. Overall, treated plants' mortality was significantly higher within the $A$ diameter class compared to the $B$ one. Treatment strongly influenced the resprouting ability of Ailanthus stems, especially in terms of sprouts' growth (Tables 2-3). The number of sprouts did not differ between seasons, regardless of diameter class. Within the $B$ diameter class, control stems produced a significantly higher number of sprouts than treated stems (Table 2). Sprouts' height in control stems was significantly higher than in treated stems (Table 3). Within the $B$ diameter class, the height of sprouts was significantly lower in NOV than in FEB and JUL. The sprouts' height did not differ between the control stems and diameter class. Since only a small number of root sprouts were observed after treatments, they have not been taken into account in the results and subsequent comments. 
Table 1. Stem mortality percentage as influenced by season and diameter class in treated $(\mathrm{T})$ and control (C) Ailanthus stems.

\begin{tabular}{lcccr}
\hline & \multicolumn{4}{c}{ Diameter class $(\mathrm{cm})$} \\
\cline { 2 - 5 } & \multicolumn{2}{c}{$A(\mathrm{DKH} \leq 8 \mathrm{~cm})$} & \multicolumn{2}{c}{$B(8<\mathrm{DKH} \leq 15 \mathrm{~cm})$} \\
\cline { 2 - 5 } Season & $T$ & $C$ & $80.0^{\mathrm{a}}$ & $C$ \\
\hline November 2011 & $100.0^{\mathrm{a}}$ & 13.3 & $53.3^{\mathrm{b}}$ & 0.0 \\
February 2012 & $73.3^{\mathrm{b}}$ & 6.7 & $66.7^{\mathrm{ab}}$ & 0.0 \\
July 2012 & $93.3^{\mathrm{a}}$ & 6.7 & 66.7 & 0.0 \\
Mean & 88.9 & 8.9 & 6.9
\end{tabular}

Notes: In each column, different letters after values, when showed, represent significant differences after Tukey's HSD test $(p \leq 0.05)$ among seasons and within the same diameter class and treatment. DKH: diameter at knee height.

Table 2. Number of sprouts $\left(\mathrm{n}^{\circ} \cdot\right.$ surviving stem -1$)$ as influenced by season and diameter class in treated (T) and control (C) Ailanthus stems.

\begin{tabular}{llllr}
\hline & \multicolumn{4}{c}{ Diameter class } \\
\cline { 2 - 5 } & \multicolumn{2}{c}{$A(\mathrm{DKH} \leq 8 \mathrm{~cm})$} & \multicolumn{2}{c}{$B(8<\mathrm{DKH} \leq 15 \mathrm{~cm})$} \\
\cline { 2 - 5 } Season & $T$ & \multicolumn{1}{c}{$C$} & 5.0 & $C$ \\
\hline November 2011 & - & 1.3 & 3.4 & 5.3 \\
February 2012 & 1.0 & 1.3 & 4.0 & 5.9 \\
July 2012 & $1.0^{*}$ & 1.2 & 4.1 & 5.1 \\
Mean & 1.0 & 1.3 & &
\end{tabular}

Notes: *Data are referred to only one stem; DKH: diameter at knee height.

Table 3. Height of sprouts $(\mathrm{cm})$ as influenced by season and diameter class in treated $(\mathrm{T})$ and control (C) Ailanthus stems.

\begin{tabular}{|c|c|c|c|c|}
\hline \multirow[b]{3}{*}{ Season } & \multicolumn{4}{|c|}{ Diameter class } \\
\hline & \multicolumn{2}{|c|}{$A(\mathrm{DKH} \leq 8 \mathrm{~cm})$} & \multicolumn{2}{|c|}{$B(8<\mathrm{DKH} \leq 15 \mathrm{~cm})$} \\
\hline & $T$ & $C$ & $T$ & $C$ \\
\hline November 2011 & - & 302.3 & $57.1^{\mathrm{b}}$ & 282.5 \\
\hline February 2012 & 35.3 & 284.9 & $111.6^{\mathrm{a}}$ & 274.2 \\
\hline July 2012 & $20.0^{*}$ & 280.9 & $130.6^{\mathrm{a}}$ & 278.3 \\
\hline Mean & 27.7 & 289.4 & 99.8 & 278.3 \\
\hline
\end{tabular}

Notes: In each column, different letters after values, when showed, represent significant differences after Tukey's HSD test $(p \leq 0.05)$ among seasons and within the same diameter class and treatment.

*Data are referred to only one stem; DKH: diameter at knee height.

\section{Discussion}

Ailanthus has been shown to successfully invade forest and urban ecosystems all around the world (Casella \& Vurro, 2013; Celesti-Grapow \& Blasi, 1998; Constán-Nava et al., 2010; DiTomaso \& Kyser, 2007; Meloche \& Murphy, 2006; Radtke et al., 2013), and 
feasible control options are urgently needed. Against the most widespread invasive plants, sometimes there are no viable alternatives to the use of chemicals, and Ailanthus is an emblematic case among woody invaders. Despite being recently listed in Europe among the invasive species for which the development of targeted programmes of biological control is strongly recommended (Sheppard, Shaw, \& Sforza, 2006), up to now specific experimentations on the matter are lacking. Therefore, the chance to limit Ailanthus spread basing on living organisms appears not to be a feasible solution, at least in a short-term perspective and within its European secondary range. In order to contain a further spread of this dangerous non-native species it is necessary to join chemical and physical treatments, as widely documented in many previous works (e.g. Constán-Nava et al., 2010). Referring to the extensive literature available, we found no investigations on the influence of the season on the efficacy of the treatments. However, this information could be extremely valuable at a management level, because it may enable a considerable increase in the feasibility as well as the economic sustainability of the control interventions, especially when considerable areas need to be cleared.

We found that Ailanthus control obtained by glyphosate through the CKHT technique was significantly affected by the timing of the application and diameter class of the treated stems. This is in line with other studies showing a strong influence of the season in the ability to recover following stem cutting in native and non-native hardwoods (Snyder, 1999), and the response was found to be species-specific. When plants are relatively small (A diameter class), excellent control may be achieved just before winter dormancy (NOV), or in the middle of the growing season (JUL), when tree mortality was found to be significantly higher than during winter dormancy (FEB; Table 1). Indeed, winter treatments (FEB) gave unsatisfactory control and more than one-fourth of the treated stems had survived after herbicide application (Table 1). Overall, in the B diameter class, mortality was significantly reduced compared with the A diameter class, meaning that doubling the application rate of glyphosate has not been enough to control larger Ailanthus stems (Table 1). However, mortality was significantly higher in NOV, but not in JUL, rather than in FEB, indicating that autumn should be preferred to perform treatments.

Since the use of higher quantities of herbicide is strongly inadvisable, especially within areas of conservation value or protected sites, our findings point out the crucial importance to treat areas invaded by Ailanthus as soon as possible. A similar difficulty to control large Ailanthus plants by glyphosate was detected by Lewis and McCarthy (2006), whereas only DiTomaso and Kyser (2007) obtained a successful control also with plants having a diameter at knee height greater than $16 \mathrm{~cm}$. In our study, this is further confirmed by the fact that all the stems larger than $15 \mathrm{~cm}$ in DKH have survived after treatments, regardless of the season (data not shown).

Treatments significantly affected mortality rates, as well as the number and height of sprouts compared to control stems. The similar sprouts height produced by the control stems, regardless of its diameter class, may be explained because the larger stems allocated their resources in a much higher number of sprouts than the smaller stems, that more often produced just one sprout.

With regard to plants in the B diameter class, despite not detecting significant differences in the number of sprouts, the growth of sprouts emerging from stems cut in November was significantly lower than in the other two seasons (Table 2). Furthermore, the sprouts' growth rate, although this has not been measured, was necessarily higher in JUL than in FEB treatments, because after summer the treated plants have had less time to recover. This suggests that the translocation of the herbicide to the root system has 
been much more effective in November, so that the subsequent sprouts have had reduced availability of resources to sustain their growth (Zhu, Xiang, Wang, \& Li, 2012). A higher effectiveness in autumn treatments was also found in the control of Ligustrum sinense Lour., a winter-deciduous shrub treated by glyphosate through foliar spray application (Harrington \& Miller, 2005).

The overview of the main studies that have dealt with Ailanthus control shows that a number of herbicides and application techniques are currently available to effectively kill Ailanthus stems, while suppressing most of the resprouts (Table 4). However, information is still lacking as regards the seasonal effect of treatments, and on the control obtained according to stem diameter. Moreover in detail, four herbicides have been generally tested: glyphosate (in five studies), imazapyr (in three studies), picloram (in two studies) and triclopyr (in four studies). Imazapyr showed undesirable effects on non-target trees and in the environment (Lewis, 2007; Lewis \& McCarthy, 2008), and it is also very difficult to find on the Italian market (Giunti et al., 2011). Picloram has been the least used, also because of its high persistence in the environment ( $\mathrm{Tu}$ et al., 2001), and cannot be administered near water bodies (DiTomaso \& Kyser, 2007), due to its high toxicity to aquatic organisms. As a matter of fact, the two herbicides most commonly used to control invasive woody species are triclopyr and glyphosate (Denny \& Goodall, 1991; Erasmus \& van Staden, 1987). However, triclopyr produced higher residue levels and suffered from much slower decomposition rates in forest soils than glyphosate (Thompson, Pitt, Buscarini, Staznik, \& Thomas, 2000), which is conversely known to have a quite low mobility in soils and is eventually inactivated by soil microbes (Busse, Ratcliff, Shestak, \& Powers, 2001; Tu et al., 2001). Nevertheless, it is also the case that some formulations of glyphosate-based herbicides cannot be administered near water bodies due to their negative effects on aquatic biota (Howe et al., 2004). Importantly, glyphosate gave satisfactory results under Mediterranean-climate conditions (Constán-Nava et al., 2010).

As regards mode of application, glyphosate can be applied into Ailanthus stems through different techniques, in standing-tree or cut-tree treatments. The main application methods available are EZ-Ject ${ }^{\circledR}$ lance, cut stump and injection (e.g. Bowker \& Stringer, 2011; DiTomaso \& Kyser, 2007). EZ-Ject ${ }^{\circledR}$ lance system, consisting of a metal lance that inserts a herbicide-filled 0.22-calibre cartridge into the stem, is a particularly effective tool but it is also quite expensive, and can be adopted only by investing significant financial resources (Bowker \& Stringer, 2011; Lewis \& McCarthy, 2006; Meloche $\&$ Murphy, 2006) (Table 3). The cut-stump technique provided contradictory results: it was really effective on young plants (Meloche \& Murphy, 2006) or if performed annually for five consecutive years (Constán-Nava et al., 2010), but by contrast DiTomaso and Kyser (2007) found that more than $40 \%$ of stems resprouted after treatments. Injection is the safest technique to minimise environmental risks posed by herbicides, also making it easier to administer the required quantity of herbicide (Badalamenti \& La Mantia, 2013); thus, it is strongly recommended for use in natural reserves and protected areas, or in their immediate proximity, where the use of chemicals is generally discouraged. Glyphosate may be injected directly in standing trees, on stumps or on knee-high cut trees (as suggested in this study), but almost no tree has died after stump injection, so this method is not recommended (DiTomaso \& Kyser, 2007). The cut at knee height, rather than at the base of the stem, facilitates the covering of the cut surface with plastic bags.

The injection into standing trees may facilitate working speed in the field since the subsequent cutting and removal of dead plants is performed in a second visit (DiTomaso 


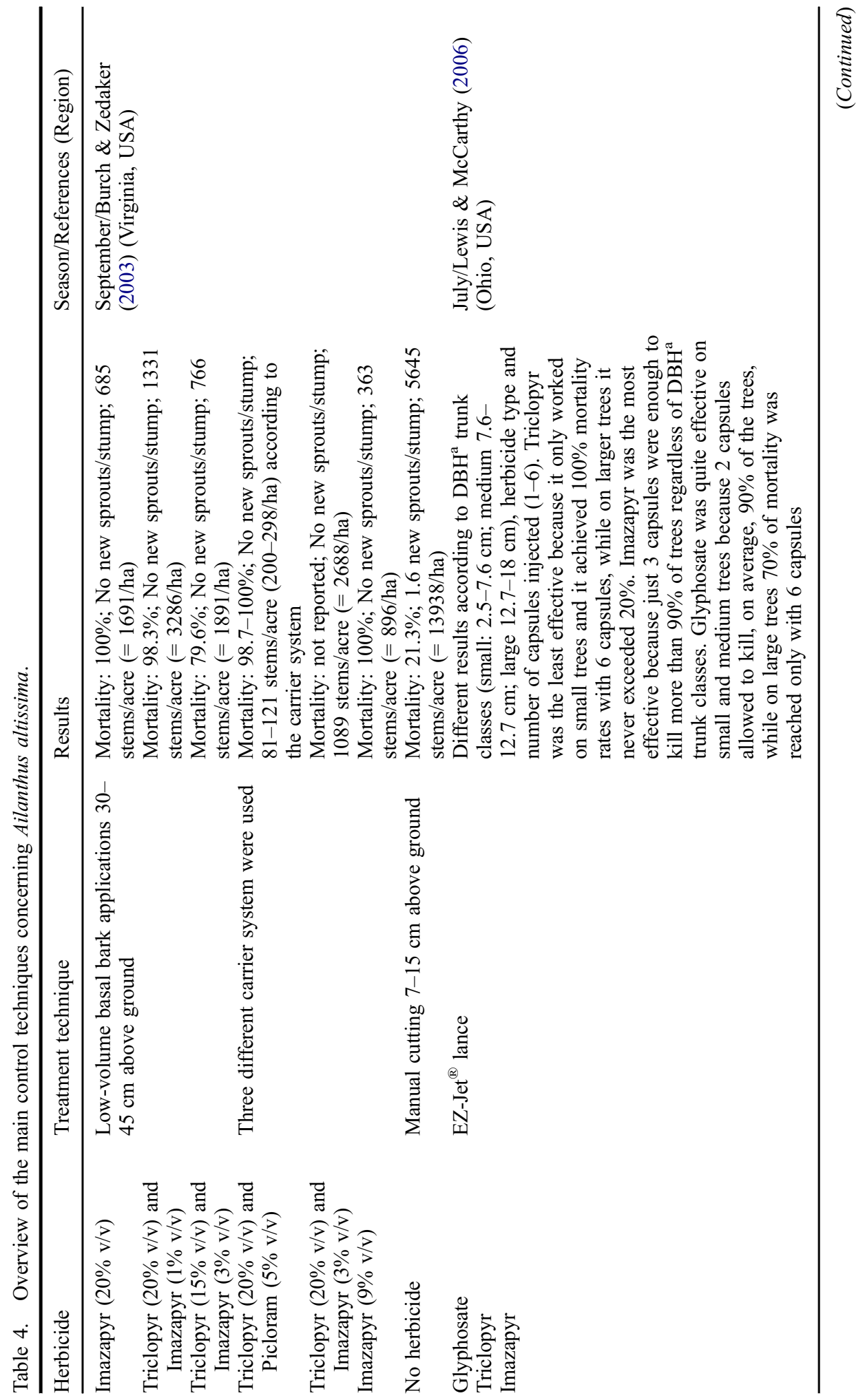




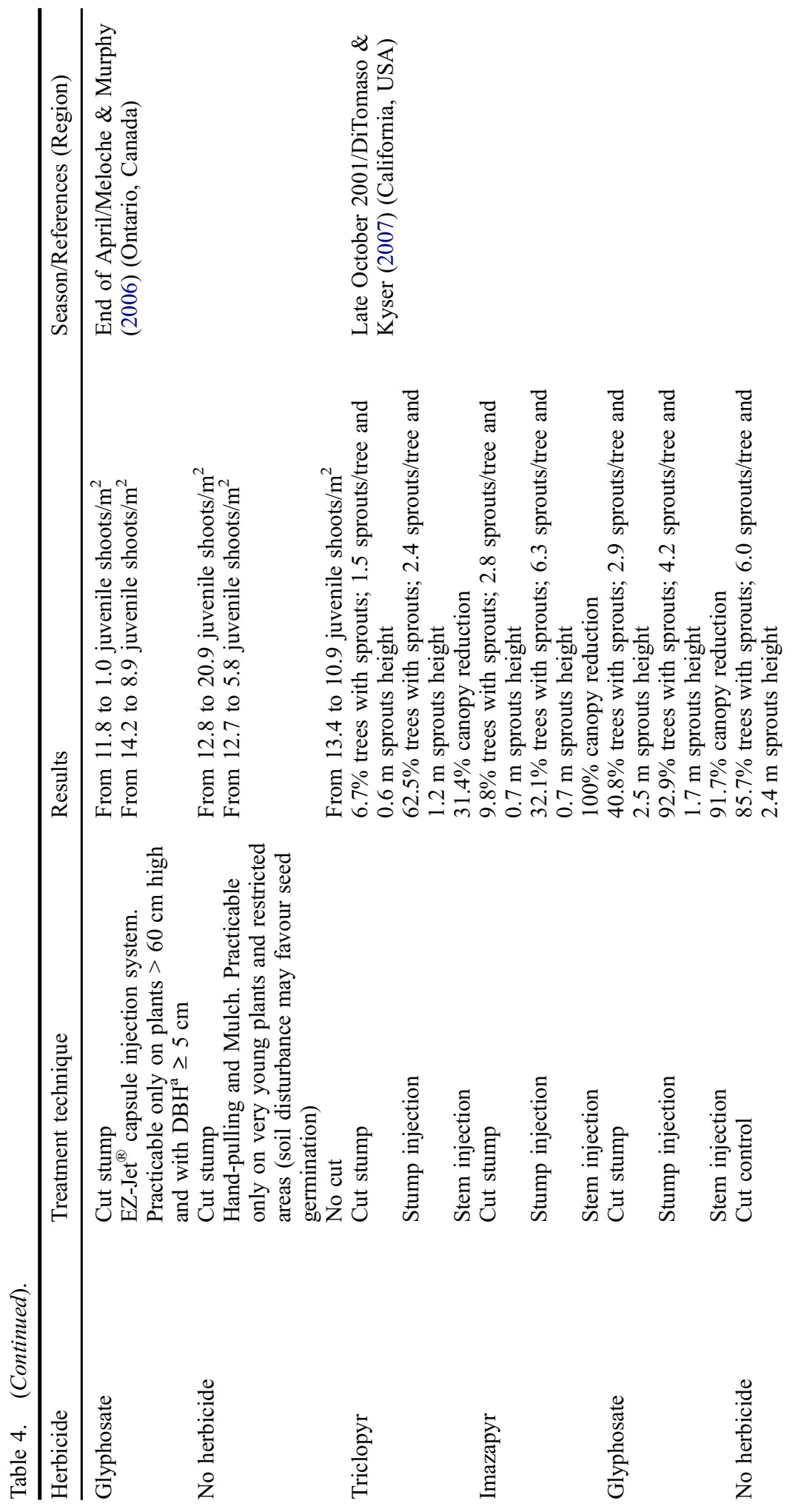



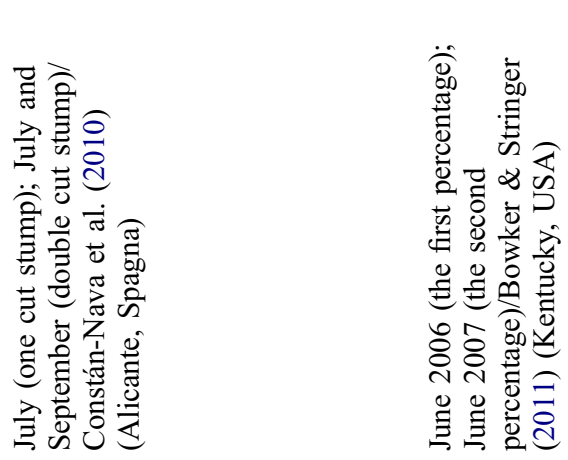

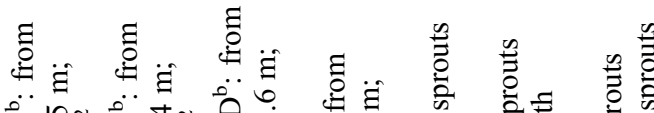

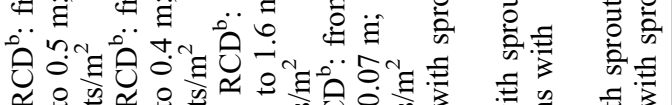

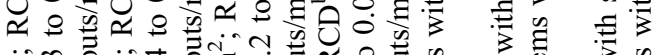

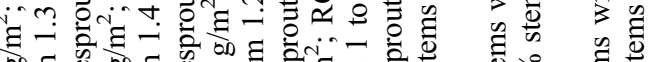

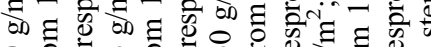

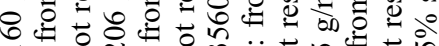

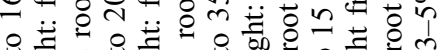

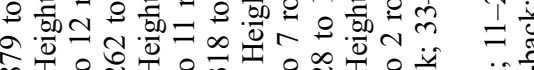

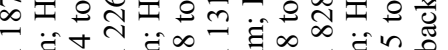

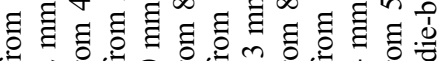

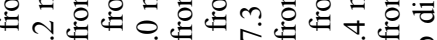

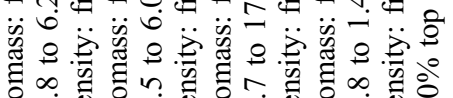

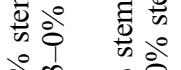
¿ें I䓵

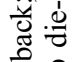
व

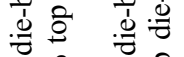

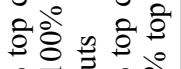

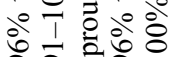

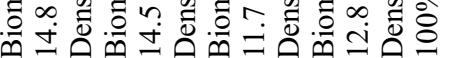

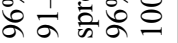

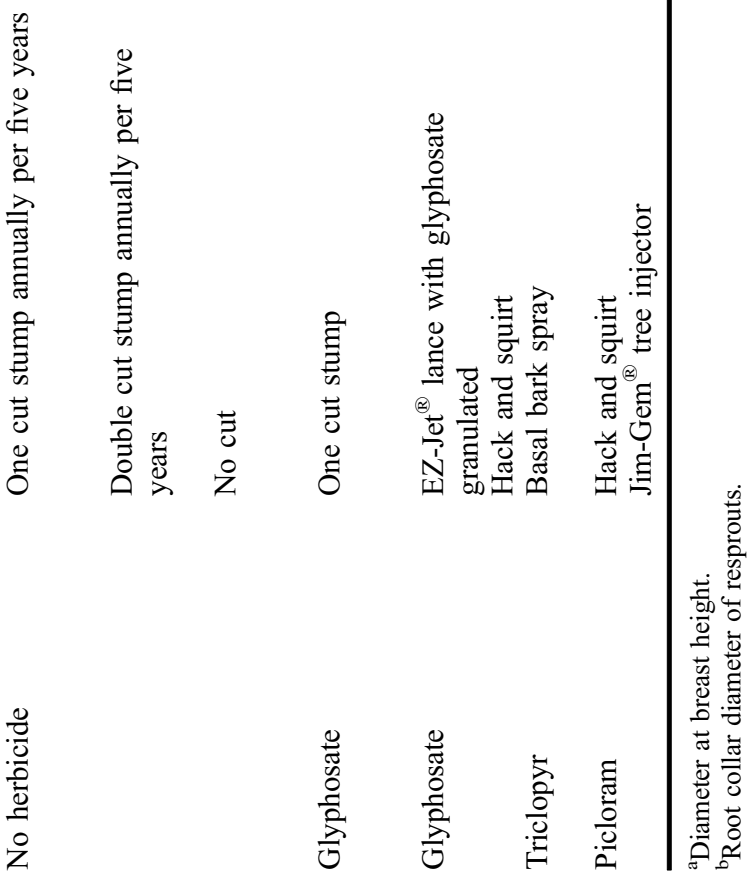


\& Kyser, 2007); a reduction of resprouts is also very likely. However, the choice to cut living plants, and, contextually to the application of glyphosate, may be advantageous for a number of reasons. First of all, the number of required operations in the control interventions is presumably lower and a reduction of economic costs is thus expected. Then, standing trees may pose a risk for both forest workers operating in the field and surrounding desirable vegetation since winds may easily cause the collapse of the dead branches of Ailanthus (pers. obs.; DiTomaso et al., 2013). Finally, the evaluation performed on cut trees is easier and more objective than on standing trees, for which the use of a subjective scale is necessary (Lewis \& McCarthy, 2006; Meloche \& Murphy, 2006).

Ultimately, we aimed at providing all the necessary information to control Ailanthus in the invaded areas. First of all, we found that a very effective method of control is obtained, on plants with a $\mathrm{DKH} \leq 8 \mathrm{~cm}$, by only performing treatments from July to November. Winter treatments are strongly discouraged because only about $70 \%$ of stems failed to resprout. For larger stems, control is quite difficult as mortality was significantly reduced. However, autumn treatments should be preferred because they lead to a high tree mortality rate and a significant curbing in regenerative capacity of treated stems, as the sprout heights, but not their number, was significantly lower than in the other two seasons. Despite single interventions being not sufficient in this case, a reduction of the need for follow-up treatments is expected. The periodic monitoring of the treated areas will allow the evaluation of the long-term effectiveness of the control measures adopted, knowing well that this will also depend on the elimination of all Ailanthus mother plants from the neighbouring areas.

\section{Conclusions}

Invasive plants are considered a growing threat to biodiversity and the ecosystem functioning of European forests (Constán-Nava et al., 2007; Green, 2003; Maringer et al., 2012; Radtke et al., 2013). Ailanthus is one of the most troublesome invaders in many habitat types including urban and suburban sites, semi-natural woodlands and shrubland. With its now undisputable spread there is a need for the adoption of appropriate and efficient control strategies. Physical treatments alone stimulate vigorous stump resprouting by Ailanthus, thus worsening the ongoing invasion process. Up to now the application of systemic herbicides represent the most effective and practical tool available, despite the potential environmental risks associated with their use. Among the available herbicides, we suggest using glyphosate because of its recognised effectiveness. Moreover it is also easily procurable in the market and it appears to be the most environmentally safe (DiTomaso \& Kyser, 2007; Giunti et al., 2011; Lewis, 2007).

Ailanthus control may be effective and cost-saving only by defining and adopting well-detailed protocols with clear and precise information on how and when to perform interventions, and this was the main aim of our research. In this respect, our findings may be of great importance for the effective management of Ailanthus. In particular, our results are consistent with previous studies, and confirm that a definitive control of Ailanthus from long-time invaded habitats is a very ambitious goal to achieve, especially through performing treatments on large plants and/or in the wrong seasons. However, control seemed to be feasible, and particularly effective, on plants having a diameter at knee height not larger than $8 \mathrm{~cm}$, through a CKHT technique, and performing the treatments just before leaf drop or in the middle of the growing season. Then, the injection into cut stems might be preferred with respect to standing trees because it 
should ensure: (1) reduction of overall economic and operating costs; (2) avoidance of risks of the hazard of tree fall because living plants are cut; (3) minimisation of the environmental threat posed by herbicide spread, due to the easier covering of treated stems.

\section{Acknowledgements}

The data reported here were obtained by the first author as part of his doctoral thesis in "Sistemi Arborei Agrari e Forestali", Department of Agricultural and Forest Sciences (SAF), University of Palermo and within the MIUR-PRIN project "Climate change mitigation strategies in tree crops and forestry in Italy (CARBOTREES)". We are really grateful to B. Massa and to the forest workers of the Department of Agricultural and Forest Sciences of Palermo for their valuable support in field activities. We also thank R. Lo Bianco, R. Massenti, A. Motisi and L. Gristina for their useful suggestions on the manuscript and their help in statistical analysis. We thank F. Quatrini for English revision. We are very grateful to Paola Mairota for his useful suggestions that improved the quality of the manuscript.

\section{Disclosure statement}

No potential conflict of interest was reported by the authors.

\section{Notes on contributors}

Emilio Badalamenti received his $\mathrm{PhD}$ in Agricultural and Forestry Systems at the University of Palermo, with a research project about "Invasive alien woody species in Sicily: regional distribution, impact assessment and control strategies". His research is mainly focused on the control and the ecophysiology of A. altissima, a widespread woody invader of Mediterranean ecosystems. He did his bachelor's thesis on the invasive process of Pennisetum setaceum, an invasive grass, and its relationship with native Mediterranean grasses.

Ettore Barone is a full professor (Pomology) at the University of Palermo (Italy) since 1 September 2000 and the director of the Department "Scienze Agrarie e Forestali" (Dept. of Agricultural and Forest Sciences). His main areas of expertise include: reproductive biology of Mediterranean fruit trees, dormancy; tree crop physiology and management of fruit tree crops; pomology and fruit species germplasm evaluation. Honours: Fellow, Consiglio Nazionale delle Ricerche - Spain - 1987; Fellow, Consiglio Nazionale delle Ricerche - USA - 1997.

Tommaso La Mantia is a researcher of silviculture at the University of Palermo. He received his $\mathrm{PhD}$ in "Ecophysiology of woody species", and is professor of "Forest Ecology" at the University of Palermo. His main fields of scientific interest and expertise include: ecology and management of forest systems, land management in protected area, effects of secondary succession on carbon storage, role of alien trees on ecosystems. He was responsible for many research projects. He is the author of more than 300 articles in national and international scientific journals and book chapters.

\section{ORCID}

Emilio Badalamenti (D) http://orcid.org/0000-0002-8178-354X

\section{References}

Aldrich, P. R., Briguglio, J. S., Kapadia, S. N., Morker, M. U., Rawal, A., Kalra, P., ... Greer, G. K. (2010). Genetic structure of the invasive tree Ailanthus altissima in eastern United States cities. Journal of Botany. Article ID 795735, 9. doi:10.1155/2010/795735 
Badalamenti, E., Barone, E., Pasta, S., Sala, G., \& La Mantia, T. (2012). Ailanthus altissima (Mill.) Swingle (fam. Simaroubaceae) in Sicilia e cenni storici sulla sua introduzione in Italia [Ailanthus altissima (Mill.) Swingle (fam. Simaroubaceae) in Sicily and historical remarks on its introduction in Italy]. Il Naturalista siciliano, S. IV, XXXVI(1), 117-164.

Badalamenti, E., \& La Mantia, T. (2013). Stem-injection of herbicide for control of Ailanthus altissima (Mill.) Swingle: A practical source of power for drilling holes in stems. iForest, 6 , 123-126. doi: 10.3832/ifor0693-006

Bowker, D., \& Stringer, J. (2011). Efficacy of herbicide treatments for controlling residual sprouting of tree-of-heaven. In S. Fei, J. M. Lhotka, J. W. Stringer, K. W. Gottschalk, \& G. W. Miller (Eds.), Proceedings of the 17th Central hardwood forest conference (pp. 128133), 5-7 April 2010. Lexington, KY: Northern Research Station, USDA Forest Service.

Burch, P. L., \& Zedaker, S. M. (2003). Removing the invasive tree Ailanthus altissima and restoring natural cover. Journal of Arboriculture, 29, 18-24.

Busse, M.D., Ratcliff, A. W., Shestak, C. J., \& Powers, R. F. (2001). Glyphosate toxicity and the effects of long-term vegetation control on soil microbial communities. Soil Biology \& Biochemistry, 33, 1777-1789. doi:10.1016/S0038-0717(01)00103-1

Camerano, P., Cullotta, S., \& Varese, P. (2011). Strumenti conoscitivi per la gestione delle risorse forestali della Sicilia [Knowledge tools for management of forest resources in Sicily] (pp. 1-192). Regione Siciliana: Tipi Forestali. Assessorato Territorio e Ambiente.

Casella, F. \& Vurro, M. (2013). Ailanthus altissima (tree of heaven): Spread and harmfulness in a case-study urban area. Arboricultural Journal: The International Journal of Urban Forestry, $35,172-181$.

Celesti-Grapow, L., \& Blasi, C. (1998). A comparison of the urban flora of different phytoclimatic regions in Italy. Global Ecology and Biogeography Letters, 7, 367-378.

Celesti-Grapow, L., \& Blasi, C. (2004). The role of alien and native weeds in the deterioration of archaeological remains in Italy. Weed Technology, 18, 1508-1513.

Celesti-Grapow, L., Pretto, F., Carli, E., \& Blasi, C. (Eds.). (2010). Flora vascolare alloctona e invasiva delle regioni d'Italia [Non-native and invasive vascular flora of the regions of Italy] (pp. 1-208). Roma: Casa Editrice Università La Sapienza.

Constán-Nava, S., Bonet, A., Pastor, E., \& Lledó, M. (2010). Long-term control of the invasive tree Ailanthus altissima: Insights from Mediterranean protected forests. Forest Ecology and Management, 260, 1058-1064.

Constán-Nava, S., Bonet, A., Terrones, B., \& Albors, J. L. (2007). Plan de actuacion para el control de la especie Ailanthus altissima en el Parque Natural del Carrascal de la Font Roja [Action plan for the control of Ailanthus altissima in the Natural Park of El Carrascal of Font Roja]. Boletín Europarc, 24, 34-38.

Denny, R. P., \& Goodall, J. M. (1991). Variable effects of glyphosate and triclopyr used for the control of American Bramble, Rubus cuneifolius agg, in pine plantations. South African Forestry Journal, 159, 11-15.

DiTomaso, J. M., \& Kyser, G. B. (2007). Control of Ailanthus altissima using stem herbicide application techniques. Arboriculture and Urban Forestry, 33, 55-63.

DiTomaso, J. M., Kyser, G. B., Oneto, S. R., Wilson, R. G., Orloff, S. B., Anderson, L. W., ... Mann, J. J. (2013). Weed control in natural areas in the western United States (pp. 1-544). Davis, CA: Weed Research and Information Center, University of California.

Drago, A., Lo Bianco, B., \& Monterosso, I. (2002). Atlante climatologico della Sicilia [Climatological atlas of Sicily]. Palermo: Assessorato Agricoltura e Foreste, Servizio Informativo Agrometereologico Siciliano. Regione Siciliana.

Erasmus, D. J., \& van Staden, J. (1987). Chemical control of Chromolaena odorata: Efficacy of triclopyr and glyphosate applied to regrowth. Applied Plant Science, 1, 39-42.

Fotiadis, G., Kyriazopoulos, A. P., \& Fraggakis, I. (2011). The behaviour of Ailanthus altissima weed and its effects on natural ecosystems. Journal of Environmental Biology, 32, 801-806.

Giunti, M., Masiaj, G., Quilghini, G., \& Sposimo, P. (2011). Interventi sperimentali per l'eradicazione dell'ailanto (Ailanthus altissima) nell'isola di Montecristo. Relazione finale del Progetto LIFE08 NAT/IT/000353 "Montecristo 2010: eradication of invasive plant and animal aliens and conservation of species/habitats in the Tuscan Archipelago, Italy". Retrieved from http://files.meetup.com/8450782/eradicazione\%20ailanto.pdf

Gómez-Aparicio, L., \& Canham, C. D. (2008). Neighbourhood analyses of the allelopathic effects of the invasive tree Ailanthus altissima in temperate forests. Journal of Ecology, 96, 447-458. 
Green, S. (2003). A review of the potential for the use of bioherbicides to control forest weeds in the UK. Forestry, 76, 285-298. doi:10.1093/forestry/76.3.285

Harrington, T. B., \& Miller, J. H. (2005). Effects of application rate, timing, and formulation of glyphosate and triclopyr on control of Chinese privet (Ligustrum sinense). Weed Technology, $19,47-54$.

Hobbs, R. J. \& Humphries, S. E. (1995). An integrated approach to the ecology and management of plant invasions. Conservation Biology, 9, 761-770.

Hoshovsky, M. C. (1988). Element stewardship abstract for Ailanthus altissima. Arlington, VA: The Nature Conservancy. Retrieved from http://www.invasive.org/gist/esadocs/documnts/ailaalt.pdf

Howe, C. M., Berrill, M., Pauli, B. D., Helbing, C. C., Werry, K., \& Veldhoen, N. (2004). Toxicity of glyphosate-based pesticides to four North American frog species. Environmental Toxicology and Chemistry, 23, 1928-1938. doi:10.1897/03-71

Impson, F. A. C., Moran, V. C., \& Hoffmann, J. H. (2004). Biological control of an alien tree, Acacia cyclops, in South Africa: Impact and dispersal of a seed-feeding weevil, Melanterius servulus. Biological Control, 29, 375-381.

Inverso, A. \& Bellani, I. (1991). Origin and development of Ailanthus glandulosa Desf. root suckers. Giornale Botanico Italiano, 125, 39-45.

Knapp, L. B. \& Canham, C. D. (2000). Invasion of an old-growth forest in New York by Ailanthus altissima: Sapling growth and recruitment in canopy gaps. Journal of the Torrey Botanical Society, 127, 307-315.

Kowarik, I. (1995). Clonal growth in Ailanthus altissima on a natural site in West Virginia. Journal of Vegetation Science, 6, 853-856.

Kowarik, I. \& Säumel, I. (2007). Biological flora of central Europe: Ailanthus altissima (Mill.) Swingle. Perspective in Plant Ecology, Evolution and Systematics, 8, 207-237.

Langeland, K. A., Ferrell, J. A., Sellers, B., MacDonald, G. E., \& Stocker, R. K. (2011). Integrated management of non-native plants in natural areas of Florida (pp. 1-27, SP 242). University of Florida, IFAS Publication. Retrieved from http://edis.ifas.ufl.edu/pdffiles/wg/wg20900.pdf

Lewis, K. (2007). Control techniques and management implications for the invasive Ailanthus altissima (tree of heaven) (Master's thesis) (pp. 1-122). University of Ohio, Athens. Retrieved from https://etd.ohiolink.edu/ap/0?0:APPLICATION_PROCESS\%3DDOWNLOAD_ETD_SUB_DO C_ACCNUM:::F1501_ID:ohiou1180128235\% 2 Cinline

Lewis, K. \& McCarthy, B. (2006). Tree-of-heaven control using herbicide injection (Ohio). Ecological Restoration, 24, 54-56.

Lewis, K. \& McCarthy, B. (2008). Nontarget tree mortality after tree-of-heaven (Ailanthus altissima) injection with imazapyr. Northern Journal of Applied Forestry, 25, 66-72.

Mack, R., Simberloff, D., Lonsdale, W., Evans, H., Clout, M., \& Bazzaz, F. A. (2000). Biotic invasions: Causes, epidemiology, global consequences, and control. Ecological Applications, $10,689-710$.

Maringer, J., Wohlgemuth, T., Neff, C., Pezzatti, G. B., \& Conedera, M. (2012). Post-fire spread of alien plant species in a mixed broad-leaved forest of the Insubric region. Flora - Morphology, Distribution, Functional Ecology of Plants, 207, 19-29.

McAvoy, T. J., Snyder, A. L., Johnson, N., Salom, S. M., \& Kok, L. T. (2012). Road survey of the invasive tree-of-heaven (Ailanthus altissima) in Virginia. Invasive Plant Science and Management, 5, 506-512.

Meggaro, Y., \& Vilà, M. (2002). Distribución y regeneración después del fuego de dos especies exóticas Ailanthus altissima y Robinia pseudoacacia en el Parque de Collserola (Barcelona) [Distribution and regeneration after fire of the two exotic species Ailanthus altissima and Robinia pseudoacacia in the Collserola Park (Barcelona)]. Montes, 68, 25-33.

Meloche, C. \& Murphy, S. D. (2006). Managing tree-of-heaven (Ailanthus altissima) in parks and protected areas: A case study of Rondeau Provincial Park (Ontario, Canada). Environmental Management, 37, 764-772.

Motta, R., Nola, P., \& Berretti, R. (2009). The rise and fall of the black locust (Robinia pseudoacacia L.) in the "Siro Negri" Forest Reserve (Lombardy, Italy): Lessons learned and future uncertainties. Annals of Forest Science, 66, Article No. 410, 10. doi:10.1051/forest/2009012

Myers, J. H., Simberloff, D., Kuris, A. M., \& Carey, J. R. (2000). Eradication revisited: dealing with exotic species. Trends in Ecology \& Evolution, 15, 316-320.

Radtke, A., Ambraß, S., Zerbe, S., Tonon, G., Fontana, V., \& Ammer, C. (2013). Traditional coppice forest management drives the invasion of Ailanthus altissima and Robinia pseudoacacia 
into deciduous forests. Forest Ecology and Management, 291, 308-317. doi:10.1016/j.foreco.2012.11.022

Sheppard, A. W., Shaw, R. H., \& Sforza, R. (2006). Top 20 environmental weeds for classical biological control in Europe: A review of opportunities, regulations and other barriers to adoption. Weed Research, 46, 93-117.

Sitzia, T., Trentanovi, G., Marini, L., Cattaneo, D., \& Semenzato, P. (2013). Assessment of hedge stand types as determinants of woody species richness in rural field margins. iForest - Biogeosciences and Forestry, 6, 201-208. doi:10.3832/ifor0749-006

Snyder, J. R. (1999). Seasonal variation in resprouting ability of native and exotic hardwoods in south Florida. In D. T. Jones, B. W. Gamble (Eds.), Proceedings of a joint conference of the exotic pest plant council and the Florida native plant society (pp. 257-269). Florida, 4-7 June 1998. Retrieved from http://www.fleppc.org/proceedings/contents.htm

Thompson, D. G., Pitt, D. G., Buscarini, T. M., Staznik, B., \& Thomas, D. R. (2000). Comparative fate of glyphosate and triclopyr herbicides in the forest floor and mineral soil of an Acadian forest regeneration site. Canadian Journal of Forest Research, 30, 1808-1816.

Traveset, A., Brundu, G., Carta, M., Mprezetou, I., Lambdon, P., Manca, M., ... Hulme, P. E. (2008). Consistent performance of invasive plant species within and among islands of the Mediterranean basin. Biological Invasions, 10, 847-858.

Tu, M., Hurd, C., Randall, J.M., \& The Nature Conservancy (2001). Weed control methods handbook: Tools and techniques for use in natural areas (pp. 220). Report No. 533. Utah Regional Depository, U.S. Government Documents, Utah State University. Retrieved from http://digital commons.usu.edu/govdocs $/ 533$

van Wilgen, B. W., Forsyth, G. G., Le Maitre, D. C., Wannenburgh, A., Kotzé, J. D. F., van den Berg, E., \& Henderson, L. (2012). An assessment of the effectiveness of a large, national-scale invasive alien plant control strategy in South Africa. Biological Conservation, 148, 28-38.

Vilà, M., Tessier, M., Suehs, C. M., Brundu, G., Carta, L., Galanidis, A., ... Hulme, P. E. (2006). Local and regional assessments of the impacts of plant invaders on vegetation structure and soil properties of Mediterranean islands. Journal of Biogeography, 33, 853-861.

Zhu, W., Xiang, J., Wang, S., \& Li, M. (2012). Resprouting ability and mobile carbohydrate reserves in an oak shrubland decline with increasing elevation on the eastern edge of the Qinghai-Tibet Plateau. Forest Ecology and Management, 278, 118-126. doi:10.1016/j.foreco.2012.04.032 